\title{
Diffuse Large B-Cell Non-Hodgkin Lymphoma Involving Multiple Different Organs in a Young Adult with ${ }^{18} \mathrm{~F}-\mathrm{FDG}$ PET/CT
}

\author{
Genç Erişkinde ${ }^{18}$ F-FDG PET/BT ile Farklı Organları lçeren Diffüz Büyük B-Hücreli Non- \\ Hodgkin Lenfoma Tutulumu
}

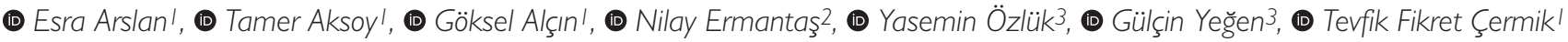

IUniversity of Health Sciences Turkey, Istanbul Training and Research Hospital, Clinic of Nuclear Medicine, Istanbul, Turkey

2University of Health Sciences Turkey, Haseki Training and Research Hospital, Clinic of Hematology, Istanbul, Turkey

3 Istanbul University, Istanbul Faculty of Medicine, Department of Pathology, Istanbul, Turkey

\begin{abstract}
Extranodal-multiorgan involvement is rarely presented in diffuse large B-cell non-Hodgkin lymphoma. ${ }^{18}$ Fluorine-fluorodeoxyglucose positron emission tomography/computed tomography findings of a 22-year-old female patient with supra/infra-diaphragmatic nodal and skeletal involvements and thyroid, pancreas, right breast, bilateral renal, and ovarian involvements were presented.

Keywords: Extranodal-multiorgan involvement, ${ }^{18} \mathrm{~F}-\mathrm{FDG}, \mathrm{PET} / \mathrm{CT}$, diffuse large B-cell non-Hodgkin lymphoma
\end{abstract}

\section{Öz}

Ekstranodal-multiorgan tutulumu, diffüz büyük B-hücreli non-Hodgkin lenfomada (DBBHNHL) nadiren görülmektedir. Yirmi iki yaşındaki kadın olguda ${ }^{18 f l o r-f l o r o d e o k s i g l u k o z ~ p o z i t r o n ~ e m i s y o n ~ t o m o g r a f i / b i l g i s a y a r l ı ~ t o m o g r a f i ~ i l e ~ D B B H N H L ' n i n ~ s u p r a / i n f r a-d i y a f r a g m a t i k ~ l e n f ~ n o d u, ~ k e m i k ~}$ tutulumu ile tiroid, pankreas, sağ meme, bilateral renal ve over tutulumu gösterildi.

Anahtar kelimeler: Ekstranodal-multiorgan tutulumu, ${ }^{18}$ F-FDG, PET/BT, diffüz büyük B hücreli non-Hodgkin lenfoma

Address for Correspondence: Esra Arslan Asst. Prof., University of Health Sciences Turkey, İstanbul Training and Research Hospital, Clinic of Nuclear Medicine, istanbul, Turkey

Phone: +90 2124596802 E-mail: dresraarslan@gmail.com ORCID ID: orcid.org/0000-0002-9222-8883

Received: 11.11.2020 Accepted: 09.01.2021

${ }^{\circ}$ Copyright 2022 by Turkish Society of Nuclear Medicine

Molecular Imaging and Radionuclide Therapy published by Galenos Yayınevi. 

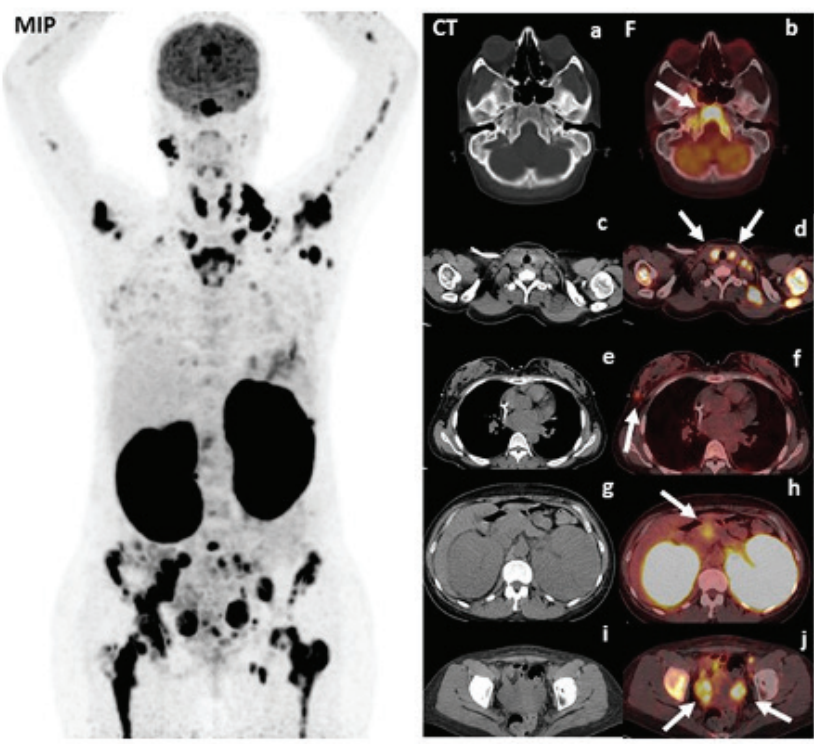

Figure 1. A 22-year-old female patient was admitted to the hospital with weakness and shortness of breath. Dialysis was started when the creatinine level was 10.95. Ultrasonography was performed, which revealed a significantly increased size of both kidneys without calculus, mass, and ectasia. A kidney biopsy was performed and reported as diffuse large B-cell non-Hodgkin lymphoma (DLBCNHL). Bone marrow biopsy was performed and large B-cell atypical mononuclear cell infiltration was detected. ${ }^{18}$ Fluorine-fluorodeoxyglucose $\left({ }^{18} \mathrm{~F}-\mathrm{FDG}\right)$ positron emission tomography/computed tomography (PET/CT) imaging was performed for staging. The maximum intensity projection (MIP) image and transaxial slices revealed focal ${ }^{18} \mathrm{~F}$-FDG uptake in the upper outer right quadrant of the right breast and at the head of the pancreas and diffuse intensive ${ }^{18} \mathrm{~F}-\mathrm{FDG}$ uptake in the thyroid, kidneys, and ovaries. Along with multiple tumoral involvements in the supra/infra-diaphragmatic lymph nodes, diffuse and focal increased multiple ${ }^{18} \mathrm{~F}-\mathrm{FDG}$ accumulations were observed in the skeleton in favor of bone marrow involvement. Axial fusion (F) images revealed increased ${ }^{18} \mathrm{~F}-\mathrm{FDG}$ uptake at skull base bone marrow, thyroid lobes, head of the pancreas, bilateral kidneys, and ovaries $F(b, d$, $f, h, j)$, and corresponding $C T$ slices $(a, c, e, g, i)$ revealed accompanying morphological findings MIP images.
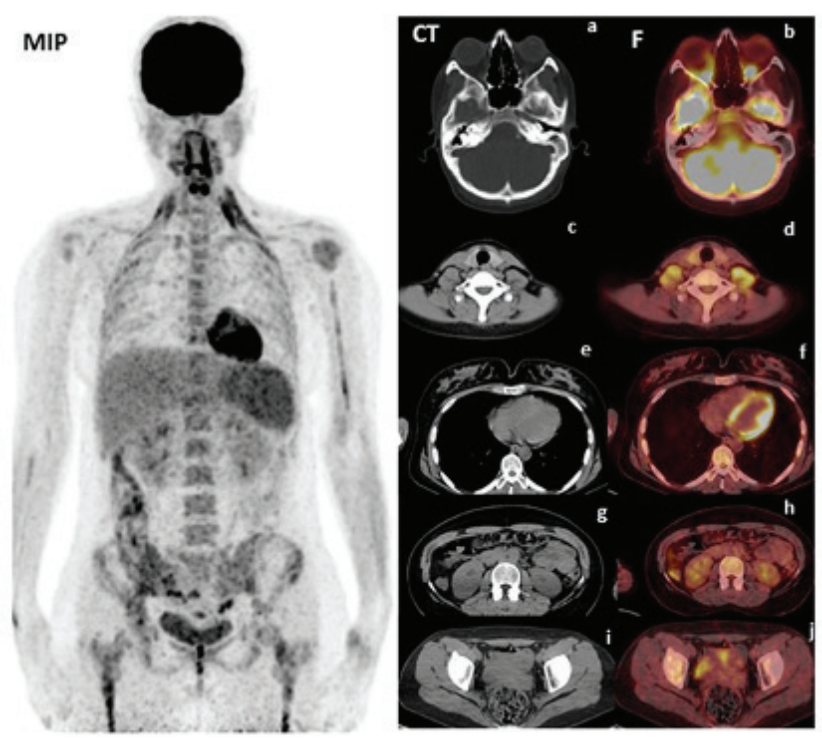

Figure 2. The rituximab, cyclophosphamide, doxorubicin, vincristine, and prednisone protocol was initiated by an adjusted renal cyclophosphamide dosage. After three cycles of chemotherapy, MIP image and axial $F$ images $(b, d, f, h, j)$ demonstrated a significant decrease in all nodal and extranodal involvements, and corresponding $C T$ slices $(a, c, e, g, i)$ revealed accompanying morphological improvements.

${ }^{18} \mathrm{~F}-\mathrm{FDG}$ PET/CT was established as the best technique for monitoring patients with extranodal involvement in $\mathrm{HL}$ and most $\mathrm{NHL}$ and must be taken into account in every stage of the disease since it can change the prognosis and treatment $(1,2)$. A study that evaluated extranodal involvements in PET/CT among lymphomas revealed that the most common organ involvements were found in DLBCNHL, and the most common organ involvement in NHL has been reported in the gastrointestinal tract (3). Uccella et al. (4) systematically reviewed the morphological, immunohistochemical, and genetic characteristics of lymphoproliferative disorders of different endocrine organs. ${ }^{18}$ F-FDG PET/ CT findings of Burkitt's lymphoma involved the spleen, brain, bones, and 4 organs in the endocrine system, including thyroid, adrenal, pancreas, and testicle, which was presented in a 21-year-old patient (5). An 11-yearold female patient with anaplastic large cell lymphoma had seven different organ involvements with ${ }^{18} \mathrm{~F}-\mathrm{FDG}$ PET/CT, which presented the muscle, bone, kidney, pancreas, ovary, lymph nodes, and central nervous system (6). Another extranodal involvement of DLBCNHL, involving left orbit and ethmoid sinus, was shown with ${ }^{18} \mathrm{~F}-\mathrm{FDG}$ PET/CT (7). Puranik et al. (8) reported a case of NHL with four rare extranodal sites, including the adrenal, peripheral nerves, pancreas, and prostate, detected with ${ }^{18} \mathrm{~F}-\mathrm{FDG}$ PET/CT.

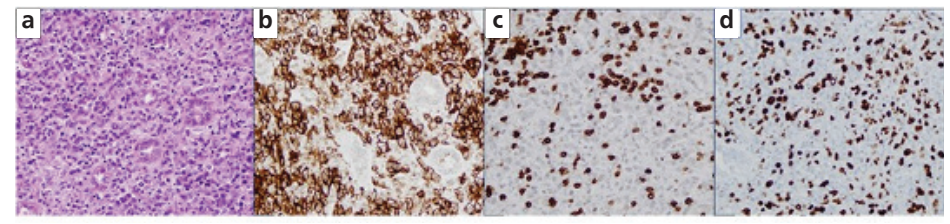

Figure 3. Renal biopsy revealed interstitial infiltration by large atypical lymphoid cells hematoxylin and eosin (a). Immunohistochemically atypical cells were positive for CD20 (b) and negative for CD3 (c). Ki67 proliferation index was high (d). 


\section{Ethics}

Informed Consent: Written informed consent was obtained.

Peer-review: Externally peer-reviewed.

\section{Authorship Contributions}

Surgical and Medical Practices: Y.Ö., G.Y., N.E., Concept: E.A., T.A., G.A., T.F.Ç., Design: E.A., T.F.Ç., Data Collection or Processing: E.A., T.A., G.A., Analysis or Interpretation: E.A., T.F.Ç., Literature Search: T.A., E.A., Writing: E.A., T.A., T.F.Ç., N.E.

Conflict of Interest: No conflict of interest was declared by the authors.

Financial Disclosure: The authors declared that this study received no financial support.

\section{References}

1. Paes FM, Kalkanis DG, Sideras PA, Serafini AN. FDG PET/CT of extranodal involvement in non-Hodgkin lymphoma and Hodgkin disease. Radiographics 2010;30:269-291.
2. Buchpiguel CA. Current status of PET/CT in the diagnosis and follow up of lymphomas. Rev Bras Hematol Hemoter 2011;33:140-147.

3. Zucca E, Conconi A, Cavalli F. Treatment of extranodal lymphomas. Best Pract Res Clin Haematol 2002;15:533-547.

4. Uccella S, Magnoli F, Amaglio C, Sessa F, La Rosa S. The spectrum of lymphoproliferative disorders in endocrine organs: from histology to molecular genetics. Diagn Histopathol 2019;25:5:166-177.

5. Wen Z, Zhuang H. Burkitt's lymphoma involving multiple hormoneproducing organs on FDG PET/CT. Clin Nucl Med 2019;44:995-997.

6. Zhang $M$, Yang $X$, Wang W, Yang J. Anaplastic large cell lymphoma involving 7 different organs in a pediatric patient demonstrated by FDG PET/CT. Clin Nucl Med 2020;45:255-257.

7. Natarajan A, Chandra P, Purandare N, Agrawal A, Shah S, Puranik A, Rangarajan $\mathrm{V}$. Role of fluorodeoxyglucose positron emission tomography/ computed tomography in various orbital malignancies. Indian J Nucl Med 2018:33:118-124.

8. Puranik $A D$, Agrawal $A$, Purandare NC, Shah $S$, Rangarajan V. Four rare extranodal sites seen on FDG PET/CT in a single patient of disseminated lymphoma. Indian J Med Paediatr Oncol 2013;34:101-103. 